\title{
Konsep Kedewasaan Subyek Hukum
}

Oleh

\author{
Ahmad Sainul \\ Dosen Fakultas Syariah dan Ilmu Hukum IAIN Padangsidimpuan \\ email : ahmadsainul@iain-padangsidimpuan.ac.id
}

\begin{abstract}
Abstrac
There is a difference in the concept of the legal maturity limit according to Islamic law and positive law. The legal subject's maturity is fifteen years old or ihtilam for men and menstruation for women. whereas according to positive law there is no legal certainty regarding legal skills in the age of 18 years, 21 years, or after marriage, resulting in confusion in determining one's skills before the law. Then the age difference in the Marriage Law for men and women needs to be equalized and needs to be re-agreed in accordance with physical and mental considerations for all parties who will get married
\end{abstract}

Kata Kunci; Konsep, Kedewasaan. Subyek, dan Hukum

\section{A. Pendahuluan}

Amir Syarifuddin mengatakan seperangkat aturan yang didasarkan pada wahyu Allah dan Sabda Rasul, tentang tingkah laku mukallaf yang diakui dan diyakini, serta bersifat mengikat untuk semua yang beragama Islam, itulah Hukum Islam. ${ }^{1}$ Landasan metodologis untuk melakukan istinbat hukum Islam dikenal dengan sebutan ushul fikih. Subyek Hukum di dalam Ushul Fiqih, hingga saat ini hanya terdiri dari manusia. Menurut Ulama Ushul Fiqh, hanya manusialah yang dapat memiliki unsur baik dan buruk, pahala dan dosa dll. oleh karena itu, manusia menjadi subyek hukum tunggal di dalam Ushul fikih.

Kriteria manusia yang dapat melakukan perbuatan hukum pun telah ditetapkan oleh Ulama-Ulama ushul fiqh terdahulu. Secara singkat dikatakan, bahwa batas laki-laki dikatakan mampu untuk dibebabani hukum Islam adalah ketika seorang laki-laki mengalami ihtilam. Batas seorang perempuan dikatakan mampu untuk dibebani hukum Islam adalah ketika haid. Ketentuan ini berimplikasi terhadap pendapat Ulama yang mengijinkan pernikahan setelah para pihak mengalami ihtilam bagi laki-laki dan mengalami haid bagi perempuan.

Pada zaman ini, ketentuan di atas perlu dikaji ulang. Pada dasarnya jika hanya didasarkan pada ihtilam dan haid, maka umur seseorang masih dikatagorikan sangat dini untuk melakukan perbuatan hukum yang memiliki resiko dan tantangan lebih besar seperti pernikahan. Perbuatan hukum yang mengandung unsur ibadah atau hanya berhubungan dengan diri sendiri seperti sholat, puasa, zakat dan lain-lain, penulis lihat masih dapat 
diterima jika menjadikan ihtilam dan haid dalam batasan minimal kedewasaan hukum, akan tetapi tidak untuk melakukan pernikahan. Ketentuan yang baru diharapkan dapat mencegah maraknya pernikahan dini yang memiliki dampak kurang baik, terutama bagi perempuan.

Pencegahan Pernikahan dini ini untuk meminimalisir akibat buruk terhadap pasangan suami isteri, terutama perempuan. Akibat tersebut bisa berupa kematian bagi ibu dan anak, karena kondisi rahim perempuan yang masih belum cukup umur dan masih belum siap untuk dibuahi. Pernikahan dini juga dapat menyebabkan maraknya perceraian, karena para pihak yang melakukan perkawinan masih belum memahami hakikat dari perkawinan. Pihak-pihak yang melakukan perkawinan dini, cenderung masih belum mampu menguasai lika liku rumah tangga secara maksimal, dikarenakan kurangnya pengetahuan tentang pernikahan, pengalaman bekerja untuk mencari nafkah dan lain-lain.

Dari fenopmena di atas, dirasa penting untuk mengkaji ulang tentang batas kedewasaan hukum untuk melakukan perintah Agama. Penulis di sini mencoba melihat fenomena tersebut dari kaca mata ushul fiqh, agar al-Quran benar-benar memberikan rahmat kepada orangorang yang beriman. Dalam masalah ini, tidak akan terlepas pula dengan mengkaji surat anNisa' ayat 6, sebagai dasar kedewasaan yang biasa digunakan di dalam Hukum Islam.

\section{B. Kedewasaan Subyek Hukum Dalam Hukum Islam}

Berbicara tentang suyek hukum dalam Hukum Islam, biasanya dikenal dengan istilah al-mahkum 'alaih. Al-mahkum 'alaih berarti seorang mukallaf yang perbuatannya berhubungan dengan Hukum Islam. ${ }^{2}$ Ada beberapa syarat yang harus dipenuhi agar seseorang disebut sebagai al-mahkum 'alaih. Jika syarat telah terpenuhi maka seorang mukallaf dapat melakukakn perbuatan hukum, untuk itu pembahasan subyek hukum ini sangat penting.

Dalam hukum Islam mininal ada dua syarat terkait dengan subyek hukum. Pertama, orang yang mukallaf harus dapat memahami dalil pembebanan. Artinya setiap Muslim yang sudah dibebani hukum peraturan-peratuan yang ada dalam al-Qur'an maupun dari as-Sunnah harus mampu memahaminya. Untuk memahami itu manusia dapat memahami nash-nash tersebut lewat akal. Akal yang tidak dapat dilihat secara indrawi, memberikan asumsi bahwa kedewasaan lah yang dapat mencerminkan akal seseorang. Seseorang telah sempurna untuk bisa diberi beban jika telah mencapai tingkat kedewasaan tanpa menampakkan sifat-sifat yang merusak kekuatan akalnya. ${ }^{3}$ Nabi Muhammad SAW bersabda tentang ini:

$$
\text { رفع القلم عن ثلاثة : عن النائم حتى يستيقظ وعن الصبي حتى يحتلم و عن المجنون حتى يعق }
$$


Tidak dapat diberikan pembebaban atas dirinya dikarenakan tidak adanya akal bagi mereka seperti orang yang tidur, anak kecil, serta orang gila. Mereka tidak dapat memahami sesuatu yang dibebankan atas mereka, oleh karenanya pembebanan tidak dapat diberikan kepada mereka. Demikian hadits di atas menunjukkan secara jelas.

Syarat subjek hukum yang kedua adalah harus yang ahli terhadap sesuatu yang dibebankan kepadanya atau disebut mukallaf. Pengertian Ahli secara etimologis adalah kelayakan. Ahli terbagi menjadi dua, yakni ahliyatul wujub (ahli wajib) dan ahliyyatul ada' (ahli melaksanakan) demikian Ulama Ushul Fiqh membagi ahli.

Pandangan lain diungkapkan oleh Kasani dari madzhab Hanafi yang juga memperbolehkan pernikahan belum dewasa. Beliau mendasarkan pendapatnya tersebut kepada tindakan Rasul yang menikahi Aisyah pada usia enam tahun. Dasar yang lain adah tindakan Nabi yang menikahkan putri Umi Kultsum dengan Ali pada waktu masih kecil. Adapula tindakan sahabat Nabi, yakni Abdullah ibn Umar yang menikahkan anaknya ketika masih kecil. ${ }^{4}$ Semua pendapat di atas menunjukkan bahwa Ulama salaf masih mengijinkan adanya praktek nikah dini.

Praktek nikah dini ini sebenarnya tidak lagi cocok jika diterapkan saat ini. Hal ini dikarenakan pernikahan dini memberikan dampak yang kurang baik terhadap pihak yang melakukan. Alasan bolehnya menikah karena para pihak telah baligh harus ditinjau kembali. Sebagaimana yang diketahui, bahwa pernikahan bukanlah akad biasa, dan tidak sama dengan akad-akad yang lain.

Perkawinan merupakan akad yang mengikat dua orang asing, yang mengharuskan para pihak untuk menguasai banyak hal. Laki-laki sebagai suami harus ahli dalam mengatur keluarganya, karena dia berperan sebagai kepala rumah tangga, harus memiliki pekerjaan untuk memberi nafkah keluarga, harus memiliki pendidikan yang memadai, karena akan menjadi imam bagi isteri dan anak-anaknya dll. Sama halnya dengan Isteri, maka isteri harus pintar dalam mengurus keuangan keluarga, karena isteri merupakan pihak yang lebih berhak dalam urusan domistik, isteri juga akan menjadi seorang ibu yang mengaharuskan memiliki kondisi fisik maupun psikologi yang matang dll.

Ahliyatul wujub adalah kelayakan seseorang disebabkan karena kewajiban dan hak-hak yang ada pada dirinya. Keahlian ini bersifat permanen pada setiap manusia, baik yang masih janin maupun baru dilahirkan, baik yang kecil maupun dewasa, atau yang memiliki akal maupun tidak. Maka dengan ini, Ahliyatul wujub ini merupakan tanda kemanusiaan, oleh karena itu semua orang pasti memiliki keahlian wajib. ${ }^{5}$ 
Ahliyatul wujub dibagi lagi ke dalam dua bagian, yakni Ahliyatul wujub yang sempurana dan Ahliyatul wujub yang kurang sempurna. Semua hak dan kewajiban semua manusia sejak lahir disebut Ahliyatul wujub yang sempurna. Seseorang yang hanya pantas diberikan hak saja, atau hanya kewajiban saja disebut Ahliyatul wujub yang kurang sempurna contoh janin yang ada di dalam perut sang ibu (yang hanya memiliki hak). ${ }^{6}$

Selanjutnya seseorang untuk diberi pembebanan, atau seseorang yang dianggap pantas oleh syara' baik dalam bentuk ucapan, maupun perbuatannya maka disebut Ahliyyatul ada'. Artinya terhadap apa yang dikerjakan mereka telah dapat dimintai pertanggungjawabannya. Kemampuan seseorang untuk membedakan baik buruk dengan menggunakan akal, inilah prinsip dasar dalam ahliyyatul ada, ${ }^{7}$

Ahliyyatul ada' dibagi lagi menjadi tiga bagian. Pertama, orang yang kehilangan atau tidak memiliki ahliyyatul ada'. Ucapan dan perbuatan yang dilakukan oleh anak-anak dan orang gila tidak dapat dimintai pertanggung jwabannya oleh syara', karena mereka dianggap tidak memiliki akal, artinya kelompok ini terdiri dari anak-anak dan orang gila. Kedua, manusia yang kurang sempurna ahliyyatul ada'nya. Kelompok ini terdiri dari orang yang kurang berakal seperti anak-anak usia remaja. Mereka tidak dapat melakukan perbuatan hukum yang bersifat pribadi yang tanpa perantara seperti menggugurkan kandungan, berbuat amal ibadah, namun remaja dan orang yang kurang berakal, berhak untuk menerima sesuatu seperti hibah, dan wasiat. Ketiga, orang yang memiliki ahliyyatul ada' secara sempurna. Kelompok ini orang yang telah baligh yang tidak terdapat tanda-tanda tentang kecacatan atau kekurangan akalnya terdiri dari orang-orang yang telah sampai pada usia dewasa dan berakal. $^{8}$

Kedewasaan seseorang di dalam hukum Islam dapat melalui beberapa aspek, hal ini dapat dilihat dari penjelasan di atas bahwa: ${ }^{9}$

1. Peranan akal

Kamus Besar Bahasa Indonesia menjelaskan tentang akal memiliki beberapa arti. Pertama, daya pikir untuk memahami sesuatu, oleh karena itu satu-satunya makhluk Allah yang memiliki akal hanya manusia. Kedua, daya upaya, ikhtiar atau cara melakukan sesuatu yakni menunjukkan dan menentukan kedewasaan seseorang dapat dilihat dari akalnya. Apabila anak tersebut telah memahami perkataan orang dan bisa memberikan tanggapan yang benar terhadap tanggapan itu, maka itulah batasan yang paling tepat untuk menguji dan menggambarkan kemampuan akal seseorang. Sesuai dengan kebiasaan yang ada di masyarakat yang ada, maka batasan kebenaran itu pun bersifat relatif. 
2. Tingkat kemampuan seorang mumayyiz

Untuk menilai seseorang dikatakan mumayyiz dilihat dari kemampuan nalar seseorang merupakan hal yang paling penting. Di tingkatan mumayiz, pada usia ini (7 tahun) seseorang belum dapat dikatakan cukup dewasa untuk melaksanakan tanggung jawab orang dewasa orang telah mampu menggunakan akalnya untuk membedakan hal yang baik dan buruk, yang berguna dan tidak, hal yang harus dilakukan dan tidak atau mereka juga masih dirasa perlu pengawasan langsung dari orang dewasa. Orang yang mumayyiz telah berhak untuk menerima hadiah dan warisan dan dapat berurusan dengan hal-hal kecil selama tidak melanggar kepentingannya, demikian Al-Mirdawi mengatakan.

3. Baligh

Melihat bentuk tubuh anak-anak yang berubah menjadi bentuk tubuh orang dewasa, adalah cara yang dapat diamati perkembangan anak dari salah satu aspek. Tanda usia seseorang dikatakan baligh ini adalah sekitar 14-15 tahunan atau mengalami ihtilam (mimpi basah) bagi laki-laki, dan mengalami haid bagi perempuan, hal ini mayoritas Ulama Salaf sepakat. ${ }^{10}$ Mampu mempertimbangkan dan memperjelas hal yang baik dan yang benar sesuai dengan ajaran agama Islam, itulah ukuran orang yang dianggap baligh. Jika tidak melakukan hal-hal yang diwajibkan di dalam agama seperti solat, puasa, orang yang baligh akan dianggap berdosa.

4. Rusyd (kedewasaan mental)

Memiliki kematangan mental, dalam arti mampu untuk berpikir jernih, itulah pencapaian rusyd berarti berupa kesempurnaan baligh. Orang yang telah mencapai rusyd adalah orang yang dapat memahami hakikat dari apa yang diperlukan dan tidak, apa yang mungkin dan tidak mungkin, apa yang penting dan tidaak penting, dan apa yang dianggap membahayakan, hal ini menurut al-Futuhi. Untuk kedudukannya di masyarakat kedewasaan mental juga dapat menentukan prestasinya di bidang apapun dan bidang yang tepat.

\section{Kecakapan Hukum Dalam Hukum Positif}

Hukum positif mengenal istilah kecakapan melakukan perbuatan hukum. Menurut MM Djojodigoeno, batas antara telah dewasa dan belum dewasa hanya dapat dilihat dari kecakapan melakukan perbuatan hukum. Mereka yang belum cakap melakukan hukum adalah orang yang belum mampu memperhitungkan dan memelihara kepentingannya sendiri. Orang yang cakap hukum berarti orang yang mampu memperhitungkan dan memelihara 
kepentingannya sendiri. ${ }^{11}$ Perbuatan hukum itu sendiri berarti perbuatan yang dilakukan oleh seseorang secara sengaja unutk menimbulkan hak dan kewajiban. Perbuatan hukum dibagi menjadi dua, yakni perbuatan hukum sepihak dan perbuatan hukum dua pihak. Oleh karena itu, kecakapan melakukan perbuatan hukum adalah kemampuan memperhitungkan dan memelihara kepentingannya sendiri dalam melakukan segala perbuatan yang dilakukan secara sengaja untuk menimbulkan hak dan kewajiban baik untuk kepentingan sendiri maupun menyangkut kepentingan orang lain. ${ }^{12}$

Dalam rangka menjamin hak-hak orang banyak, maka hukum positif memberikan batasan umur seseornag dapat dikatakan cakap hukum. Kecakapan hukum dalam hukum positif memilki beraneka ragam ketentuan. Hal ini dapat disebabkan karena kondisi sosial yang melatar belakangi ketika aturan tersebut dibuat. Sebagaimana yang diketahui, bahwa ada beberapa aturan yang mengatakan bahwa anak adalah seseorang yang memiliki umur di bawah delapan belas tahun. ${ }^{13}$ Aturan ini berimplikasi bahwa orang yang dewasa adalah orang yang umurnya di atas delapan belas tahun.

Aturan yang lain tentang batasan kedewasaan adalah aturan dalam Kompilasi Hukum Islam. Kompilasi Hukum Islam mengatakan bahwa orang dapat dikatakan dewasa adalah berumur 21 tahun. Hal ini berlaku bagi semua orang yang tidak mengalami cacat fisik maupun mental dan belum pernah melakukan perkawinan. ${ }^{14}$ Dalam kitab Undang-Undang Hukum Perdata juga mengatakan bahwa seseorang dikatakan dewasa apabila telah mencapai umur 21 tahun. Apabila seseorang telah melakukakn perkawinan, maka orang tersebut menurut Undang Undang Hukum Perdata telah dikatakan dewasa. ${ }^{15}$ Kecakapan hukum di atas tidak berlaku apabila orang yang bersangkutan mengalami sakit ingatan, keadaan dungu dan pemborosan. ${ }^{16}$ Ukuran pemborosan didasarkan pada kesepakatan hakim. ${ }^{17}$

\section{Kedewasaan Subyek Hukum Dalam Melakukan Perkawinan}

Perkawinan dalam Undang-Undang Perkawinan diartikan sebagai: ikatan lahir batin antara seorang pria dengan seorang wanita sebagai suami isteri dengan tujuan membentuk keluarga (rumah tangga) yang bahagia dan kekal berdasarkan Ketuhanan Yang Maha Esa. ${ }^{18}$ Pengertian di atas menunjukkan bahwa perkawinan bukanlah ikatan yang mengikat secara batin (tidak terlihat), akan tetapi secara lahir (dapat dilihat) pula. Secara lahir berarti ada peran fungsi fisik ketika seseorang telah melakukan perkawinan.

Salah satu cara untuk mewujudkan tujuan dalam perkawinan adalah dengan adanya batasan minimal umur dalam perkawinan. Hal ini dirasa penting, karena orang yang di bawah 
umur dianggap belum mampu menjalani kehidupan keluarga yang penuh dengan tantangan. Batasan umur ini pun tidak diatur secara jelas di dalam al-Qur'an dan as-Sunnah. Oleh karena itu, para Ulama salaf memiliki pandangan yang berbeda terkait dengan umur perkawinan. Undang-Undang perkawinan dan Kompilasi Hukum Islam sepakat, bahwa batas minimal umur perempuan adalah 16 tahun dan 19 tahun untuk laki-laki. ${ }^{19}$

Meniliki perkawinan dalam hukum Islam, mayoritas imam madzhab yang empat lebih cenderung masih membolehkan perkawinan wanita yang belum dewasa. Hal ini terbukti sebagaimana Imam Maliki berpendapat: bahwa perkawinan seorang janda yang belum dewasa dan belum dicampuri oleh bekas suaminya, baik ditalak amaupun ditinggal mati, maka statusnya sama dengan gadis. Bapak juga memiliki hak ijbar bagi gadis tersebut. Apabila telah dicampuri, maka statusnya menjadi janda dan bapak tidak memiliki hak ijbar atas anak tersebut, sehingga anak lebih berhak kepada dirinya sendiri. ${ }^{20}$

Imam Syafi'i secara tidak langsung juga memperbolehkan pernikahan di bawah dini. Hal ini dapat dilihat dari tiga macam perkawinan menurut imam Syafi'i. Pertama adalah perkawinan janda, kedua adalah perkawinan gadis dewasa, dan ketiga adalah perkawinan anak. imam Syafi'i memperboleh gadis yang belum dewasa untuk melakukan perkawinan dengan batasan belum berumur lima belas tahun atau belum haid. ${ }^{21}$

Menurut madzhab Hanbali yang diwakilkan oleh Ibn Qudamah juga memperbolehkan menikahi gadis yang belum dewasa. Beliau mendasarkan pendapatnya ini kepada firman Allah:

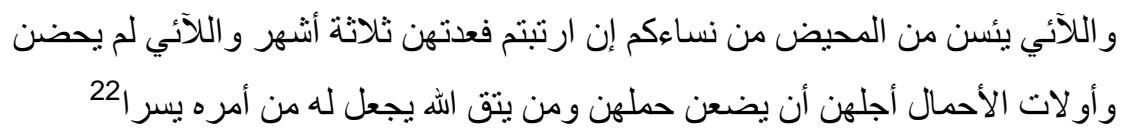

Secara tersirat ayat di atas menunjukkan bahwa seorang perempuan yang belum haid atau belum dewasa boleh melakukan perkawinan. Hal ini dikarenakan, ayat di atas menerangkan tentang iddah bagi perempuan yang tidak haid, baik karena belum haid, maupun karena sudah putus haid. ${ }^{23}$

Pandangan lain diungkapkan oleh Kasani dari madzhab Hanafi yang juga memperbolehkan pernikahan belum dewasa. Beliau mendasarkan pendapatnya tersebut kepada tindakan Rasul yang menikahi Aisyah pada usia enam tahun. Dasar yang lain adah tindakan Nabi yang menikahkan putri Umi Kultsum dengan Ali pada waktu masih kecil. Adapula tindakan sahabat Nabi, yakni Abdullah ibn Umar yang menikahkan anaknya ketika masih kecil. ${ }^{24}$ Semua pendapat di atas menunjukkan bahwa Ulama salaf masih mengijinkan adanya praktek nikah dini. 
Praktek nikah dini ini sebenarnya tidak lagi cocok jika diterapkan saat ini. Hal ini dikarenakan pernikahan dini memberikan dampak yang kurang baik terhadap pihak yang melakukan. Alasan bolehnya menikah karena para pihak telah baligh harus ditinjau kembali. Sebagaimana yang diketahui, bahwa pernikahan bukanlah akad biasa, dan tidak sama dengan akad-akad yang lain.

Perkawinan merupakan akad yang mengikat dua orang asing, yang mengharuskan para pihak untuk menguasai banyak hal. Laki-laki sebagai suami harus ahli dalam mengatur keluarganya, karena dia berperan sebagai kepala rumah tangga, harus memiliki pekerjaan untuk memberi nafkah keluarga, harus memiliki pendidikan yang memadai, karena akan menjadi imam bagi isteri dan anak-anaknya dll. Sama halnya dengan Isteri, maka isteri harus pintar dalam mengurus keuangan keluarga, karena isteri merupakan pihak yang lebih berhak dalam urusan domistik, isteri juga akan menjadi seorang ibu yang mengaharuskan memiliki kondisi fisik maupun psikologi yang matang dll.

Menurut ilmu kedokteran, memiliki resiko yang lebih tinggi pada kesehatan perempuan jika kehamilan usia muda (dibawah usia 20 tahun). Karena memiliki organ reproduksi yang belum siap dan beresiko tinggi mengalami kondisi kesehatan yang buruk saat hamil, demikian kondisi perempuan di bawah 20 tahun. Dikhawatirkan akan menggangu perkembangan janin, karena kondisi sel telur perempuan di bawah usia 20 tahun juga belum sempurna. Bagi perempuan ada beberapa kondisi kesehatan yang mungkin terjadi, di antaranya kelahiran prematur yaitu kelahiran di bawah usia kandungan di bawah 37 minggu dan memiliki tekanan darah tinggi pada ibu hamil. Tidak hanya terhadap ibu, beberapa kondisi lain yang dikhawatirkan adalah berat badan bayi yang rendah saat lahir dan mengalami depresi postpartum. Artinya ada rasa kecemasan setelah melahirkan. Resiko kematian ibu yang tinggi dikarenakan terjadinya pendarahan dan infeksi, hal ini dampak yang paling mengerikan. Pemeriksaan ahli medis harus dilakukan dengan ekstra mengingat kondisi yang sangat rawan di usia kehamilan remaja, meskipun kondisi kesehatan setiap individu berbeda-beda. $^{25}$

Perempuan berusia 21-35 tahun resiko gangguan kesehatan pada ibu hamil menurun, hanya sekitar $15 \%$. Perempuan pada kisaran usia ini telah memiliki kematangan reproduksi, emosional maupun aspek sosial, demikian apabila dilihat dari perkembangan kematangan. Pada umumnya kisaran usia ini merupakan usia yang ideal untuk perempuan mengalami kehamilan dan melahirkan. Perempuan pada usia 24 tahun mengalami puncak kesuburan dan 
pada usia selanjutnya yakni 25 tahun ke atas perempuan mengalami penurunan kesuburan akan tetapi masih tetap bisa hamil, dekimian sebuah ahli mengatakan. ${ }^{26}$

Dalam Alquran, kehamilan dinyatakan sebagai proses reproduksi yang sangat berat : حملته أمه وهنا على وهن (ibunya telah mengandungnya dalam keadaan lemah yang berganda). ${ }^{27}$ Di dalam ayat yang lain dikatakan حملته أمه كر ها ووضعته كرها (ibunya mengandung dengan susah payah, dan melahirkan dengan susah payah). ${ }^{28}$ Ayat di atas menunjukkan, bahwa proses kehamilan dan melahirkan bukanlah proses yang mudah bagi seorang perempuan, oleh karena itu butuh kesiapan fisik dan mental yang penuh untuk menjalani proses kehamilan dan melahirkan. Laki-laki (suami) yang tidak mungkin merasakan proses kehamilan dan melahirkan, setidaknya semampu mungkin mampu mendukung isteri untuk melewati masamasa yang tidak mudah tersebut. Inilah pentingnya seorang laki-laki yang dewasa bagi isterinya.

Dari situasi dan kondisi di atas dapat disimpulkan, bahwa batasan minimal usia pernikahan dalam Undang-Undang Perkawinan, yakni 16 tahun untuk perempuan dan 19 tahun untuk laki-laki perlu ditinjau kembali. Penulis menyarankan, idealnya antara laki-laki dan perempuan tidak perlu memiliki aturan yang berbeda terkait umur perkawinan. Laki-laki dan perempuan harus sama-sama matang baik fisik maupun mentalnya untuk melangsungkan perkawinan. Usia kematangan laki-laki dan perempuan dengan pertimbangan-pertimbangan yang telah dipaparkan sebelumnya adalah sekitar umur 21 tahun.

\section{E. Makna Ar-Rusyd dalam Surat an-Nisa' (4): 6 Menurut Ulama'}

Berbicara tentang batasan umur perkawinan, tidak jarang Ulama-Ulama yang menggunakan Surat an-Nisa' (4): 6 sebagai dasar hukum seseorang dibolehkan untuk menikah. Oleh karena itu, dirasa penting untuk mengkaji ulang tentang keberadaan ayat tersebut. Ulama yang tidak asing lagi di dalam kajian tafsir, yakni Bapak Quraish Syihab, memaknai kata rusyd dengan ketepatan dan kelurusan jalan. Menurut beliau, dengan kata rusyd tersebut dimaksudkan agar manusia harus sempurna akal dan jiwanya. Oleh karena itu, seperti yang dikutip oleh beliau tentang pendapat Imam al-Ghazali, bahwa orang yang telah menyandang rasyid, adalah dia yang mengalir penanganan dan usahanya ke tujuan yang tepat, tanpa petunjuk pembenaran atau bimbingan dari siapapun. ${ }^{29}$

Imam Syafi'i lebih cenderung menjadikan ayat tersebut sebagai dalil tentang pengelolaan harta anak yatim. Menurut beliau, apabila seseorang telah baligh dan cerdas, maka orang tersebut telah dianggap mampu untuk mengelola hartanya sendiri. Baligh oleh 
imam Syafi'i diartikan sebagai genap menginjak usia lima belas tahun baik bagi laki-laki maupun perempuan. Definisi tersebut berlaku bagi laki-laki yang belum mimpi basah dan bagi perempuan yang belum haid. Cerdas oleh imam Syafi'i diartikan sebagai kelayakan dalam beragama sehingga diperbolehkan syahadat, dan juga kemampuan untuk mengelola harta dengan baik. Syarat kecerdasan dan baligh yang dipaparkan oleh imam Syafi'i harus benar-benar terpenuhi keseluruhannya. Apabila seseorang hanya memenuhi salah satunya, yakni baligh tapi tidak cerdas atau cerdas tapi belum baligh, maka orang tersebut dianggap belum mampu untuk mengelola hartanya sendiri. ${ }^{30}$

Pandangan lain diungkapkan oleh Kasani dari madzhab Hanafi yang juga memperbolehkan pernikahan belum dewasa. Beliau mendasarkan pendapatnya tersebut kepada tindakan Rasul yang menikahi Aisyah pada usia enam tahun. Dasar yang lain adah tindakan Nabi yang menikahkan putri Umi Kultsum dengan Ali pada waktu masih kecil. Adapula tindakan sahabat Nabi, yakni Abdullah ibn Umar yang menikahkan anaknya ketika masih kecil. ${ }^{31}$ Semua pendapat di atas menunjukkan bahwa Ulama salaf masih mengijinkan adanya praktek nikah dini.

Praktek nikah dini ini sebenarnya tidak lagi cocok jika diterapkan saat ini. Hal ini dikarenakan pernikahan dini memberikan dampak yang kurang baik terhadap pihak yang melakukan. Alasan bolehnya menikah karena para pihak telah baligh harus ditinjau kembali. Sebagaimana yang diketahui, bahwa pernikahan bukanlah akad biasa, dan tidak sama dengan akad-akad yang lain.

Perkawinan merupakan akad yang mengikat dua orang asing, yang mengharuskan para pihak untuk menguasai banyak hal. Laki-laki sebagai suami harus ahli dalam mengatur keluarganya, karena dia berperan sebagai kepala rumah tangga, harus memiliki pekerjaan untuk memberi nafkah keluarga, harus memiliki pendidikan yang memadai, karena akan menjadi imam bagi isteri dan anak-anaknya dll. Sama halnya dengan Isteri, maka isteri harus pintar dalam mengurus keuangan keluarga, karena isteri merupakan pihak yang lebih berhak dalam urusan domistik, isteri juga akan menjadi seorang ibu yang mengaharuskan memiliki kondisi fisik maupun psikologi yang matang dll.

Imam Syafi'i juga berpendapat tentang batas usia kecukupan menikah dari ayat tersebut. Menurut beliau, kecukupan usia seseorang untuk melakukan pernikahan adalah lima belas tahun. Seseorang yang belum genap lima belas tahun, akan tetapi telah mimpi basah (laki-laki) dan haid (perempuan), diperbolehkan pula untuk melakukan pernikahan. Apabila 
seseorang telah melakukan pernikahan, maka orang tersebut telah dianggap mampu untuk melakukan sebuah perbuatan hukum dan mampu mempertanggungjawabkan perbuatannya. ${ }^{32}$

Al-Maraghi berpendapat bahwa untuk menguji kedewasaan seseorang adalah dengan memberikan sedikit harta kepadanya. Apabila orang tersebut telah mampu mempergunakan harta dengan sebaik-baiknya, maka orang tersebut dapat disebut dewasa. Dewasa menurut beliau adalah ketika seseorang telah mengerti dengan baik cara menggunakan harta benda dan membelanjakannya. Hal ini membuktikan bahwa orang tersebut memilki akal yang sehat, sehingga dapat berpikir dengan baik. ${ }^{33}$

Dari pendapat-pendapat Ulama di atas, dapat dilihat bahwa Quraish syihab lebih cocok dalam mengartikan kata ar-rusyd. Beliau lebih menekankan bahwa hakikat dari kata ar-rusyd adalah kesempurnaan akal dan jiwa seseorang untuk melakukakn suatu perbuatan, bukan hanya sekedar haid bagi perempuan dan mimpi basah bagi laki-laki. Tercapainya kesempurnaan akal dan jiwa ini sangat penting, untuk mewujudkan perbuatan yang mashlahah untuk semua pihak, baik yang melakukan itu sendiri, atau orang-orang yang disekitarnya. Oleh karena itu, setiap orang harus benar-benar diuji terkait kesempurnaan akal dan jiwanya, terutama dalam akad-akad yang memiliki resiko lebih umum, seperti pernikahan, perjanjian internasional dan lain-lain.

Maka dalam hukum Islam, seseorang dijatuhi kewajiban baik itu ibadah maupun hal yang lainnya terutama terhadap sesuatu yang sangat krusial maka dalam hukum Islam sangat memperhatikan kedewasaan atau yang sering disebut mukallaf atau kedewasaan yang menjadi ukuran kecakapan dan kemapanan seorang insan manusia dalam berfikir dan bertindak. $^{34}$

\section{F. Penutup}

Dari penjelasan yang telah dipaparkan di atas, maka dapat ditarik kesimpulan:

1. Batas kedewasaan subyek hukum dalam hukum Islam yang baru sebatas umur 15 tahun atau ihtilam bagi laki-laki dan haid bagi perempuan sudah tidak dapat lagi diterapkan untuk perbuatan hukum yang memiliki hubungan dan dampak yang lebih umum dan lebih besar, seperti pernikahan, perjanjian dll.

2. Belum adanya kepastian hukum mengenai kecakapan hukum dalam Hukum Positif, yakni umur 18 tahun, 21 tahun, atau setelah melakukan pernikahan, mengakibatkan kerancuan dalam menentukan kecakapan seseorang di mata hukum. 
3. Perlu adanya pengkajian ulang dan kesepakatan terhadap penentuan batas kedewasaan, agar dapat menghasilkan batas kedewasaan yang lebih relevan.

4. Perbedaan umur dalam UU Perkawinan bagi laki-laki dan perempuan perlu disamakan dan perlu disepakati kembali sesuai dengan pertimbangan fisik dan mental bagi semua pihak yang akan melakukan pernikahan.

5. Pentingnya pemahaman kata Ar-Rusyd (kedewasaan mental) dalam Surat an-Nisa' (4): 6, harus benar-benar diterapakan dalam perbuatan hukum yang bersifat umum.

End Note :

${ }^{1}$ Dadan Muttaqien, Cakap Hukum Tentang Perkawinan dan Perjanjian (Yogyakarta: Insania Citra Press, 2006), hlm. 16.

${ }^{2}$ Abdul Wahab Khalaf, Ilmu Ushulul Fiqh, (Mesir: Da'wah Islamiyah Syabab al-Azhar, 1968), alih bahasa oleh Masdar Helmy, Ilmu Ushul Fiqh (Bandung: Gema Risalah Press, 1996), hlm. 229.

${ }^{3}$ Ibid, hlm. 230-232.

${ }^{4}$ Ibid, hlm. 372.

${ }_{6}^{5}$ Abdul Wahab Khalaf, Ilmu Ushulul Fiqh, hlm. 233.

${ }^{6} \mathrm{Ibid}$, hlm. 234-5.

${ }^{7} \mathrm{Ibid}, \mathrm{hlm} .233-4$.

${ }^{8}$ Ibid, hlm. 235-7

${ }^{9}$ Dadan Muttaqien, Cakap Hukum, hlm. 2-12.

${ }^{10}$ Ibid, hlm. 18.

${ }^{11}$ Ibid, hlm. 15.

${ }^{12} \mathrm{Ibid}$, hlm. 15-16.

${ }^{13}$ Convention on the Rights of the child, Pasal 1: "anak berarti setiap manusia yang berusia di bawah delapan belas tahun".

${ }^{14}$ Kompilasi Hukum Islam, Pasal 98 ayat (1).

${ }^{15}$ Kitab Undang-Undang Hukum Perdata, Pasal 1330.

${ }^{16}$ Kitab Undang-Undang Hukum Perdata Pasal 433 jo. Pasal 1330.

${ }^{17}$ Dadan Muttaqien, Cakap Hukum, hlm. 27.

${ }^{18}$ Undang-undang Nomor 1Tahun 1974 tentang Perkawinan, Pasal 1.

${ }^{19}$ Undang-Undang Nomor 1 Tentang Perkawinan dan Kompilasi Hukum Islam

${ }^{20}$ Khoirudiin Nasution, Hukum Perdata (Keluarga) Islam Indonesia Dan Perbandingan Hukum Perkawinan Di Dunia Islam (Yogyakrta: ACAdeMIA+TAZZAFA, 2009), hlm.371.

${ }^{21}$ Ibid, hlm. 372.

${ }^{22}$ At-Talaq (65): 4.

${ }^{23}$ Khoiruddin Nasution, Hukum Perdata (Keluarga) Islam hlm. 373.

${ }^{24} \mathrm{Ibid}$, hlm. 372.

${ }^{25}$ http://bidanku.com, Revina, “Usia Ideal Wanita Untuk Hamil Dan Melahirkan”, diakses tanggal 5 November 2014.

${ }^{26} \mathrm{Ibid}$

${ }^{27}$ Luqman (31):14.

${ }_{29}^{28}$ Al-Ahqaf (46): 15.

${ }^{29}$ M. Quraish Syihab, Tafsir al-Mishbah Pesan, Kesan dan Keserasian al-Qur'an, vol: 2 (Jakarta: Lentera Hati, 2002), hlm. 351.

${ }^{30}$ Ahmad Mushtafa al-Farran, tafsir al-Imam Asy-Syafi'i (Jakarta: Almahira, 2007), hlm. 21-23.

${ }^{31} \mathrm{Ibid}, \mathrm{hlm} .372$.

${ }^{32} \mathrm{Ibid}$, hlm. 23-24.

${ }^{33}$ Ahmad mustafa al-Maraghi, terjemah tafsir al-Maraghi, jil ke-4(Semarang: CV Toha Putra, 1993), $h \operatorname{lm} 340$. 
${ }^{34}$ Hendra Gunawan, “Karakteristik Hukum Islam” pada Jurnal Al-Maqasid: Jurnal Ilmu Kesyariahan dan Keperdataan Fakultas Syariah dan Ilmu Hukum IAIN Padangsidimpuan, Volume 4 Nomor 2 Edisi JuliDesember 2019, hlm. 105-125.

\section{DAFTAR PUSTAKA}

Qurais Shihab, Sejarah dan Ulumul Quran, Jakarta: Pustaka Firdaus, 2000.

Alquran dan Terjemahan, Jakarta: Departemen Agama, 2001.

Muhammad Ali Ash-Shabuni, At-Tibyan Fi Ulum al-Quran, terj. Muhammad Qadirun Nur, Ikhtisar Ulumul Quran Praktis,Jakarta: Pustaka Amani, 2001.

Muhammad Hashim Kamali, Prinsip-Prinsip dan Teori- Teori Hukum Islam, terj. Yogyakarta: Pustaka Pelajar, 1996.

Harun Nasution, Islam Ditinjau Dari Berbagai Aspeknya, Jakarta: UI Press, 1978.

Dede Rosyada, Hukum Islam dan Pranata Sosial, Jakarta: Raja Grafindo Persada, 1996.

Abdullah Ahmad An-Naim, Dekonstruksi Syari'ah, terj. Ahmad Suedy, Yogyakarta: Pustaka Pelajar, 1994.

As-Sarkhasi, Ushul as-Sarkhasi, jil. II, Beirut: Dar al-Kutub al-Ilmiyah, 1993.

Abdul Wahab Kh.af, Kaidah-Kaidah Hukum Islam, Jakarta: Rajawali, 1996.

As-Syafi ${ }^{\text {ee }}$, al-Umm, Beirut: Dar Fikr, t.t..

Gunawan, Hendra,. "Karakteristik Hukum Islam” pada Jurnal Al-Maqasid: Jurnal Ilmu Kesyariahan dan Keperdataan Fakultas Syariah dan Ilmu Hukum IAIN Padangsidimpuan, Volume 4 Nomor 2 Edisi Juli-Desember 2019, hlm. 105-125. 